\title{
Historical Places of Interest, BOOKS, TOURISM AND AdVertising: SCOTtISH ICONS IN Contemporary Halifax (Nova Scotia)
}

There is none more Scots than the Scots abroad. (Spirit of the West)

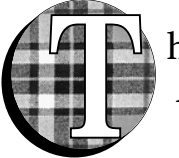
he first attempt of a Scottish settlement in North America was a failure. After he was granted permission to colonize, Sir William Alexander officially named the new colony Nova Scotia, New Scotland, in 1621. Although the first Scottish settlement appeared in 1629, immigration for real did not start until after the Seven Years War and after the expulsion of the previous French Acadian settlers in 1759. Despite the complex colonial history of the Province, the original coat of arms showing the Scottish connection (St. Andrew's Cross and the rampant lion in the middle of the crest), granted in 1625 , has been kept as a permanent symbol of the province throughout its colonial history and up until today.

The aim of this article is to trace the origin and show the presence of Scottish icons in contemporary Halifax. In particular, the research focuses on the Scottish images presented to the public. The analysis of these Scottish symbols starts from the historical places of interests related to Scotland, which represent the oldest connection to the fatherland. Secondly, this discussion focuses on some of the printed sources available in Halifax, which establishes a link to either Scotland or the Scots in Nova Scotia. In particular, for the purpose of this article, the analysis focuses on the Scottish imagery presented to the readers. Thirdly, a critical analysis looks at
\end{abstract}


the commercial use of Scottish imagery by the tourist and advertising industry in Nova Scotia.

In order to understand the evolution of Scottish culture (and, consequently, of its representations) in Canada, it is fundamental to take into consideration the main political, social and economic factors that led to the migration. In addition to these, it is crucial to remember the cultural background that the Scots packed in their intellectual and psychological luggage on their way to the New World. These three main factors (political-social, economic and cultural) appear to have influenced the development of Scottish culture abroad, when we look at the history and the causes of the Scottish immigration.

Firstly, Scotland had just undergone one of the most dramatically celebrated episodes of its history. The defeat of Bonnie Prince Charlie's army at Culloden in 1745 brought drastic social changes to the Highland society. The clan system virtually ceased to exist, as private ownership was to substitute the traditional feudal system. The end of the clan system meant the cutting of the previous bonding that existed among clan members. Moreover, the political and social changes occurring after Culloden were marked by the ban on the wearing of the tartan (repealed only in 1789).

Secondly, major economic changes took place in the Highlands between the end of the eighteenth and the second half of the nineteenth century and represented another relevant factor for the Scottish Diaspora. The start of a new kind of economic exploitation - in terms of capitalist agriculture and intensive sheep breeding - culminated in the Highland Clearances, a process of serious depopulation which would last until the 1860s. The intensive emigration triggered by the Highland Clearances was inevitably going to affect the face of the new Scottish communities which were growing larger and more numerous all over the New World.

Thirdly, cultural changes had taken place in Scotland at the time when immigration reached its peak, between the end of the eighteenth and throughout the nineteenth century. The outburst and development of the Romantic Movement that 
was inflaming intellectuals all over Europe did not leave the Scottish nation untouched. In fact, it is in this context that the Highlands and its inhabitants started to be the object of the mythopoetic literary imagination across Europe. In the wilderness of the landscape and the alleged wildness of its dwellers was identified the re-incarnation of the 'noblesavage', a myth developed towards the end of the Enlightenment and later become a central concept in the Pre-Romantic movement. ${ }^{\mathrm{i}}$

In this cultural frame, Scotland saw the rise of two distinguished figures in the literary scene: Robert Burns and Sir Walter Scott. The passionate feelings towards Scottish traditions and cultural identity embodied by Burns's poetry were echoed, later, in the creation of a mythical Scotland and an idealized heroic interpretation of its history portrayed in Scott's novels. The cult of a romantic Scotland, the worship of its bards Burns and the fake Ossian and the myth of its savage Highlanders, became symbols of the romantic search of identity for the Romantic intellectuals all over Europe, as well as the foundation of the myth of the Scottish immigration in Canada.ii

From the start, the making of the Scottish myth both in Europe and in Canada focused on a romanticized concept of the Highlands. It is not a mere coincidence that Highland Societies started to mushroom all over North America virtually at the same time as in Britain. In fact, Halifax NorthBritish Society (renamed The Scots since 1995) - the oldest institution of the kind in Canada - was founded in 1768, ten years earlier than the Highland Society in London. Whether or not the Highland connection was justified in some way or another, all Canadian Scottish societies flouted Highland symbols as icons of their cultural identity. Bagpipes and kilts started to play a fundamental role in any of the manifestations organized by the societies, including 'Burns suppers' and the popular Highland Games (held for the first time in Halifax in 1845 and Antigonish in 1863). These 'were not exclusively patronized by Scots, but [they] represented Scottish identity at its most colorful and most conspicuous 
and provided fertile fields for the invention of tradition'.ii

Behind the Highland emblems stood Scots from all social and geographical backgrounds. Upper- and working-class, Highlanders and Lowlanders, soldiers and peasants would all bond in the name of a peaceful coexistence, which they had seldom experienced in their fatherland. Most likely though, even this re-established harmony within the New World Scottish society was only a myth. As Cowan suggests: 'in point of fact, the often considerable antipathy between Lowlander and Highlander which existed in the Old Country was frequently exported to the New World'. iv

It is interesting to notice how the memory of the Highlands would change in the creation of a new Scottish mythology shared by the immigrants. Rusty Bitterman has stressed the discrepancies in the Scottish immigrants' attitudes (and consequent interpretations) towards the agrarian transformations of the Highlands, according to their social background. It was mainly the upper class that encouraged the development of the Highland myth. The concept of an idyllic Scottish society in the New World did not leave space to an open critique of the capitalist transformation of the Highlands in the Old World. Symptomatically, the Highland Clearances were hardly ever mentioned, because somehow they did not fit in the romantic model that was being created. $v$

Historical accounts and mythical reinterpretation of the Scottish immigration in Canada do not follow the same path. In fact, on many occasions, the later creation of Scottish migration mythology betrays an obvious distortion of the actual events. The glorious group of Scottish immigrants who arrived on board the Hector in 1773 represents the most celebrated episode of the Scots migration to Nova Scotia. This historical landmark has acquired a mythical aura equaling the Mayflower's fame, ever since its dramatic landing on the shores of Pictou.vi

More recently the fame of the Hector was celebrated by the successful reproduction of the mythical ship launched in Pictou in September 2000. Already in 1999 the tourist brochure Sunrise Trail: Heritage Tour included a picture 
portraying the re-enactment of the Scottish arrival in Pictou: a red bearded Scotsman, dressed up in traditional tartan attire, including kilt, sporran and a jacket with shiny, newly-polished brass buttons. It is unlikely that the Scots on board of the Hector could have looked so glamorous after such a long and strenuous journey! Furthermore, as Cowan has observed, it is not credible that they would wear kilts at all. In fact, the ban on the wearing of kilts was only repealed in 1789. Afterwards, tartan started to be fashionable mainly among those who could afford it, and consequently became a real upper-class status symbol: 'the fanciful notion of starving Highlanders in ragged kilts struggling ashore at Pictou off the Hector in 1773 is thus entirely false'. vii

Ironically, a new 'Ship Hector Tartan', designed by Janice Gammon was registered with Scottish Tartan Society in 1999, in preparation of the Hector re-enactment celebration. Tartan imagery, undoubtedly, represents one of the most effective systems of cultural symbols easily identified by tourists, a factor that seems to have provided a relevant incentive to the Hector project, as confirmed in an article published in the Pictou Advocate:

Once built, the Hector will be an essential part of Pictou County's tourism industry and will provide substantial economic benefits to the town of Pictou. [...] It will also stand a lasting memorial to the Scottish settlers who first came into Pictou harbor in 1773. viii

The emphasis given to the financial benefits implied in the project has perhaps lessened the commemorative and cultural value of the initiative. The last section of this article will go into a deeper analysis of the role played by the tourist industry in the development of the Scottish imagery in Halifax.

Finally, before going into a deeper analysis of Scottish icons in Halifax, it might be worth having a look at some statistics and data concerning Halifax and Nova Scotia at the threshold between the twentieth and the twenty-first century. 
In the 1830s the Scots represented the largest ethnic group in Nova Scotia, but by 1871 their number had dropped to just one third of the population. The 1921 census shows the higher proportions of the immigrants with English origin (39\%) against those with Scottish ancestry (28\%).ix In 1996 the proportion seemed to have increased slightly in favor of the Scots who represented 32\% of the total population of Nova Scotia while the English population had decreased to $37 \% . \mathrm{x}$ As for the capital, according to census compiled in 1996, Halifax had a population of 94,900 inhabitants with Scottish ethnic origin, $28.5 \%$ of the total population, outnumbered by the 131,685 with an English ancestry (39.6\%).xi

Although the Scots do not seem to represent the largest ethnic group any longer, the presence of Scottish culture in Nova Scotia and in Halifax is still very strong. Scholars have noted how the development of the Scottishness in Nova Scotia was greatly encouraged by the rise of tourist industry. ${ }^{\text {ii }}$ In particular, the role of Nova Scotia Scottish Premier Angus L. Macdonald gave a definite stir to the events in the 1930s. Macdonald promoted Scottish culture as the main traditional heritage in Nova Scotia. He supported the foundation of St. Ann's Gaelic College in Cape Breton as well as the construction and improvement of the Cabot Trail, now promoted as the most scenic route in Nova Scotia.

Behind all the initiatives undertaken by Macdonald, stood his own patriotic feelings for his ancestry. In particular, as stressed by Iain MacKay, Macdonald's views concerning Scotland focused only on the Highlands and the clans, an ideology that went back to the romantic myth of Scotland, shared by the immigrants from the very beginning. This is why MacKay describes Macdonald's policy in terms of 'antimodernism', an attitude towards the historical past that became the main angle through which folk-traditions were made the center of interest and started a trend in Nova Scotia.xiii 'Tartanism', in MacKay's words, 'the system of signs testifying to the supposed Scottish essence of Nova Scotia', xiv is the result of a long-standing policy in order to promote the Scottishness of Nova Scotia. How can the present situation 
relate to it? Do the Scottish icons still have a genuine meaning? Or is it just a mere post-modernist version of tartanism with no other reason to exist but the economic profits from the tourist industry? This analysis will address these issues and attempt to interpret the depth of contemporary Scottish icons in Halifax.

This journey through the Scottish icons in Halifax starts with its monuments and historical sites. There are seven Scottish-related places of interests in Halifax: Point Pleasant Park, Burns' Monument, Scott's Bust, Menstrie Castle Cairn, St. Mary's University, Dalhousie University and Halifax Citadel. As far as Scottish vestiges are concerned, Point Pleasant Park holds two features of interest: the heather and the lamp posts. The patch of heather in Halifax Southernmost point has been the object of debate dating as far back as 1878 . A series of letters to the editor of the Morning Chronicle testifies the lively interest raised by the plant in August 1878. Most of the correspondents suggested that the heather had been imported from Scotland. An anonymous H., however, strongly disagreed with these interpretations, as he believed the plant was nothing but North American in its origin:

In the first place, I am utterly at a loss to know - as I am sure most of your readers must be - what business anybody has to call the plant in question 'Scotch heather', even supposing it to be an exotic - which is not. It could with just as much property be called 'Welsh heather', or 'Irish heather', or 'Scandinavian heather', if we had to go abroad to find a genealogy for it. ${ }^{x v}$

The author of the letter claims to contradict the stereotype that any heather originates from Scotland. The Editor, on the other hand, feels he has to warn that this letter might touch a delicate matter as far as the Scottish community is concerned:

The Heather question is one of the most interesting of the day. 'H.', whose letter we publish today, makes sad havoc with the cherished ideas 
of some of our Scottish citizens. He will never be forgiven for asserting that Heather might properly be called Welsh, Irish or Scandinavian. ${ }^{\text {xvi }}$

In 1928, an article on Dalhousie Review presented a brief summary of some of the several versions of the same legend about the origin of the heather in Point Pleasant. According to some, the heather in Point Pleasant came from nowhere but from the pockets of the founder of Nova Scotia. Sir William Alexander aimed indeed at the creation of a new 'Land of Heather' in North America.xvii According to others, the soldiers of the Black Watch regiment camping in Point Pleasant in 1757 planted the seeds. Whether the heather seeds were planted by the men 'being desirous of perpetuating the badge of so many of their clansmen' or accidentally fell off their mattresses, the plant had definitely a Highland origin. ${ }^{x v i i i}$ The truth is the heather (Calluna vulgaris) has definitely been imported to North America from Europe. Nonetheless, it is not certain whether it really came from Scotland. It is clear that, regardless of scientific evidence, heather has played an important role as a persistent symbol of Scottishness, in the creation of the Scots mythography in Nova Scotia. Incidentally, it might be interesting to observe that at the time of the heather debate, the population of Scots had already decreased to one third of the total inhabitants of Nova Scotia.xix

At the entrance of Point Pleasant Park stand five old gas lamp-posts. Each of them bears an inscription: 'GLASGOW CORPORATION LIGHTING DEPARTMENT 1900'. On the side next to the text is another piece of evidence about their origin: the tree, the bird, the fish and the bell of Glasgow coat of arms. A Gen. K. C. Appleyard gave the lamp posts to the city of Halifax in 1967. Although their Scottish origin could not have been more obvious, this is how the local newspaper commented on the episode in the article "Monstrosities" for The Park": 'Five old English lamp standards, and one of three old horse watering troughs donated to Halifax by British industrialist Gen. K. C. Appleyard are to be located in Point Pleasant Park'. ${ }^{x x}$ It is strange that a Nova Scotian 
newspaper such as the Halifax Mailstar would not only fail to highlight the Scottish connection of the gifts, but even odder that the editors would dismiss it altogether. Why have the lamp posts, the only original Scottish monuments present in Halifax (besides the stones of Menstrie Castle Cairn) not become the object of a more obvious public display? A possible answer to this strange dismissal could lie in the origin of the lamp posts, since they did not originate from the heart of the Highlands, or from the historical capital of Scotland, Edinburgh. The gift, from a not yet very glamorous industrial Glasgow, bore the Lowlands trademark. Moreover, Glasgow's image and rough reputation, only promoted by the tourist industry in the last fifteen years and its nomination as European City of Culture in 1990, would have definitely failed to fit the romantic Scottish myth in the 1960s. xxi

The path followed by the initiatives promoted by the North British Society in Halifax perfectly fits this myth. The monuments chosen to represent Scottishness in Halifax all bare strong connections with a romantic view of Scotland. Symptomatically, Burns and Scott are chosen as the most representative Scottish poets, while Menstrie Castle Cairn was built with the stones from an old Scottish castle. Halifax Burns Monument was erected in Victoria Park on September $13^{\text {th }} 1919,160$ years after the death of the celebrated bard. The decision to erect a monument to the most celebrated of the Scottish poets suggests the will to give Halifax a public emblem of the connection with the fatherland. An article commented on the unveiling of the monument referring to the Bard from 'Old Scotland', highlighting the strong boundary between 'Old' and 'New Scotland'.

The aim to perpetrate the familial links between Scotland and Nova Scotia was made more manifest by the erection of the Scott Bust at the entrance of the Public Gardens on September $21^{\text {st }} 1932$, the $100^{\text {th }}$ anniversary of Scott's death. The bust was the only copy in North America of the Chantrey Bust in Scott's Library at Abbotsford. The erection of the monument was preceded by great expectation and utmost excitement on behalf of the Committee appointed by 
the North British Society for the monument. In one of the relevant documents, Chief Justice J. A. Chilsom stated that 'It will probably be the only memorial of the kind in the Western world'; Chilsom also kept a regular correspondence with Major General Maxwell Scott to whom he wrote these enthusiastic lines:

I cannot express too highly my appreciation of your kindness in this matter in giving us an opportunity of commemorating here in Halifax in so an exceptional way your illustrious ancestor, Sir Walter Scott. Apart from other consideration, it is not inappropriate that in the Capital city of new Scotland, we should keep alive the name and memory of the great man who brought so much reknown of Old Scotland. $x x i$

Once again, the romantic myth of Scotland comes forward as celebrated by Sir Walter Scott's work. In addition to this, Chilsom mentioned 'the educative value to the young people; fostering interest in higher things' in his speech before the presentation of the monument.xxii

Menstrie Castle Cairn (1957) is situated a little further south from the Burns Monument. Perhaps the least famous of the monuments patronized by the North British Society, nonetheless, it is the only one made of 'original' Scottish material. The Cairn was erected to celebrate the memory of Sir William Alexander with stones from Menstrie Castle, birthplace of the founder of Nova Scotia. In an article commenting on the shipping of the stones from Scotland to Nova Scotia 'free of charge', it is noted that: 'People in Scotland are aware of the genuine interest and close ties between their country and the people of New Scotland'. The same comment seems to be shared on the other side of the Atlantic, as Lord Wemys, Chairman of the National Trust for Scotland said of Nova Scotia: 'It is a great community which is so important to Scotland, and which regards Scotland as so important to itself'; the article also mentioned Lord Wemys's fear that 'The province [...] would suffer a great disaster if its 
people could see nothing more of Scotland's past than her lovely hills'.xxiv

What would have mattered to the English, the French, the Mi 'kmaq and all the other Non-Scottish ethnic groups if the Scottish past had been completely erased from Nova Scotia? It is clear that in 1957, although the Scottish community was not any longer the most numerous ethnic group of the province, Nova Scotia still felt essentially Scottish. Other interesting facts emerge from the history of the two colleges in Halifax. Reverend Edmund Burke founded St. Mary's University, the oldest University in Halifax, in 1802. Facing financial hardship from the very beginning, the uncertain future of the college was rescued in 1913 by the initiatives of the Christian Brothers of Ireland who directed it until it was taken over by the Jesuit Fathers in 1940.

It was in the 1940 s that Daniel Fogarty, S.J., designed St. Mary's University coat of arms. As stated in the University Calendar, 'each symbol in the crest has a significance relevant to the various phases and history of the University'.xxv The motto 'Age Quod Agis' is taken from the Irish Christian Brothers, while the official seal of the Jesuits stands in the middle of the shield. Beside other religious and academic symbols, there are two crowns representing the college's loyalty towards the Dominion of Canada and the British Commonwealth; last, but not least, 'is the thistle, which stands for Nova Scotia's Scottish heritage'.xxvi Although the Scots did not play any relevant role in the history of St. Mary's University, the Scottish heritage, once again, appears as representative of the cultural history of the Province.

The history of Dalhousie University's foundation is rather peculiar. As we read on an official inscription opposite to the Clock Building:

In September 1814, a British military and naval expedition from Halifax, under Lieutenant General Sir John Coape Sherbrooke and Rear Admiral Edward Griffith, occupied the portion of Maine between Penobscot and St. Croix Rivers. 
Major General Gérard Gosselin governed that district from Castine, until 26th April 1815. Governor Dalhousie utilized the Custom Duties collected during this period for the endowment of the Garrison Library and Dalhousie College.

According to P.B. Waite, Lord Dalhousie found himself with a considerable sum of money after the Peace of Ghent (1814) and considered his options carefully. After the first thought of investing the amount in Halifax King's College, he decided to create a new college on the model of the University of Edinburgh, the institution he attended in the capital of his fatherland. Having obtained permission, Dalhousie College was officially opened on 22 May 1820.xxvii Dalhousie University has been using the Earl of Dalhousie's coat of arms virtually ever since its foundation, although, technically speaking, this has never been made official. Despite the fact the Scottish icons used are less obvious to a profane eye than the thistle on St. Mary's University's crest, Dalhousie's emblem is, undoubtedly, a Scottish import.xxviii

Halifax Citadel represents the stronghold of Scottishness in Halifax. Acknowledged as one of the most important historic sites in Canada and undoubtedly the most impressive monument in Halifax, the Citadel has come to represent another emblem of the Scottish influence on the city and the Province. Completed in 1856, the present Citadel is the final evolution of four subsequent forts, built by the British army in order to protect the city from an eventual American attack. The Citadel, however, has never been attacked, and since 1951 has concluded its military career to become a National Historic Site. Visitors heading towards the entrance of the site encounter a welcome sign portraying a full-size image of a Highlander. Once inside the building they are entertained by the historical animation program organized by Parks Canada. This includes arms drill, bayonet exercise and firing demonstration performed by students dressed up in kilts of the MacKenzie tartan like original $78^{\text {th }}$ Highlanders. These performances are alternated or accompanied by the 
music of the pipers who again are dressed up to resemble the $78^{\text {th }}$ pipers.

The $78^{\text {th }}$ Highland Regiment occupied the Citadel during the years 1869-71. Before and after them many (non-Scottish) regiments dwelt in the barracks of the fort. Yet, the Highlanders have been chosen to represent all the military history of the Citadel. Several reasons seem to have led to this decision. In one of the Management Plans of the Citadel it is suggested that the $78^{\text {th }}$ was chosen because the Highlanders occupied the Citadel for quite a lengthy period of time when the fort reached its greatest status. ${ }^{x x i x}$ Elsewhere, it is suggested that the Haligonians received the Highlanders particularly warmly.xxx This is how the Highlanders were welcomed to Nova Scotia, according to an article entitled 'The Kilties':

The 78th Highlanders landed on Saturday morning and marched to the quarters assigned to them - some at the [militia] drill shed, Spring Garden Road, some at the Citadel. They presented a fine appearance. It is a long time since Halifax had a regiment wearing the kilt, and the appearance of the men created quite a sensation. ${ }^{\text {xxxi }}$

Similar comments are to be found in the Halifax Evening Reporter, the British Colonist and the Halifax Citizen and even in some of the religious papers such as the Presbyterian Witness and the Christian Messenger.xxxii The main emphasis focused on the tartan attire that definitely made a strong impression on the Haligonians. Perhaps some critics could interpret this enthusiasm as a pre-manifestation of 'tartanism', later used by Parks Canada to attract more visitors to the Citadel. Or maybe it was just the sheer excitement raised by the charming looks of the Highlanders who sailed back after two and a half years with a small 'army' of seventeen Nova Scotian women they had married during their stay.xxxii

Although it cannot be denied that a genuine enthusiasm on behalf of the population in Halifax was involved in the 
history of the $78^{\text {th }}$ Regiment at the Citadel, it is, on the other hand, a fact that the Scottish imagery has been used ad abundantiam in the advertising strategies of Parks Canada. Commenting on the success achieved by the Regiment's pipers, this is what is recorded on one of Parks Canada Information Sheets: 'No doubt the pipes and drums added a touch of Scottish color quite appropriate to the capital of a province called Nova Scotia'.xxxiv It is definitely more than 'a touch of Scottish color', that can be experienced today at the Citadel. Pipes and ceilidh music can be heard on the way to the Citadel gift shop. And as the visitors browse around it, being tempted to take a souvenir back home, they cannot but be dazzled by the incredible amount of (pseudo) Scottish things that crowd the place.

Halifax Citadel Gift Shop represents a good source for all sorts of publications about the Scots and Scotland. It is hardly surprising that Highland Scotland with its clans and haunted castles dominate the themes generally covered by the available works. As for their packaging, the cover illustrations feature ubiquitous kilted Highlanders, pipers, scary ghosts and cute Highland cows. The list of Scottish-related printed material could be endless. This, however, does not claim to be a complete survey of all the available sources in Halifax. The works quoted in this section have been chosen to be representative of what can be found in Halifax. The next section will focus on publications concerning the Scottish immigration. The criteria used to select the sources lie mainly on the visual presentation of the products. It will be noted how, once again, the main emphasis is given to the Highlands, the clans, and tartan imagery. Tartan, here, becomes a semantic universal sign for anything related to Scottish people, history and culture.

This section looks at Scottish periodicals available in Halifax - Celtic Heritage and The Scottish Banner - and three selected recent publications on Scottish themes - Marjorie Major's How Nova Scotia Got Its Tartan (1996), R. A. MacLean's A State of Mind: The Scots in Nova Scotia (1992) and F. Emerson's Scots (1997). Celtic Heritage, a magazine about 
things Scottish, is published in Halifax. Articles on various subjects focus mainly on the Gaelic traditions and Highland Scotland. Celtic Heritage is also available in Gaelic. The Scottish themes are clearly conceived for a North-American audience: a great interest is shown towards genealogy, giving the readers useful tips for their genealogical searches. The magazine offers also a North-American perspective on Scottish ancestry and Clan Societies advertise here from all over the continent.

An interesting letter entitled 'Scots not Considered a Culture' published in Celtic Heritage in April 1999, discloses the reader's complaints on the lack of financial support from the government towards any of the activities organized by Scottish Societies. Here, the Scottishness of Nova Scotia is perceived through the eyes of an unhappy Scotsman abroad:

Scots emigrants have tolerated ignorance when their kilts are called skirts or their music likened to screeching cats. They endure jokes about drunks that nearly always feature a Scot or an Irishman. They are denigrated as mean, tight, stubborn, dour, penny-pinchers- a people of little value. [...] When you see the 'tartan people', remember that they are proud of their Scottish ancestry [...]. xxxv

It is hard to believe that anybody could ever doubt the pride Scots immigrants have of their ancestry, as demonstrated by the number of Scottish/Celtic initiatives and cultural manifestations throughout the province. Canadian Scots feel frustrated by the colorful clichés attached to their nationality and yet they are willing to show their national pride more manifestly. Clearly, the popular consensus is that the Scots have become victims of the Highland myth they have created for their own good. Who is, then, responsible for the creation of the Scottish myth and, consequently, its misinterpretation?

The red rampant lion on the left and the Scottish flag on the right decorate The Scottish Banner's logo. 'The largest Scottish newspaper in the world outside Scotland' holds, besides the 
main articles on Scotland and Scottish events in North America, sections on cooking ('In The Scottish Kitchen'), crosswords ('scotwords'): and brief news from Scotland ('Scot Snips'). In the issue published in April 1999, a first-page article on 'Tartan Day', a North-American invention to celebrate Scottishness abroad.xxxvi Here, the wish is expressed that people would wear a bit of tartan on April $6^{\text {th }}$, whatever their national background. The issues also feature advertising campaigns for all sort of Scottish-related business: from holiday packages to the Scottish fatherland to stained glass nameplates available in the colors of each clan.

Marjorie Major's How Nova Scotia Got Its Tartan comes with a paperback cover with the map of Nova Scotia, the tartan, the flag and the Gaelic greeting: 'Ciad Mile Failte'.xxxvii The booklet tells the reader how the new tartan was actually created to avoid jealousies among Scottish clans in Nova Scotia. During the 1953 Farm and Fisheries Exhibition, Mrs Douglas Murray was commissioned a textile panel describing the history of sheep breeding in the province. The shepherd featured in the middle of the panel had to be Scottish. When it came to weave the colors of the tartan, Mrs Murray (who, incidentally, was English) decided to design a Nova Scotia tartan, so as not to offend any members of the already existing Scottish Clans.

Ten years after the exhibition, the tartan became officially part of the Nova Scotia heraldry in 1963. During those ten years, Nova Scotia Premier Macdonald worked hard to obtain permission to acknowledge the new tartan from Scotland. Old Scotland was concerned that Scottish clans in Nova Scotia encouraged to wear the provincial tartan might forget their Scottish ancestry. This, of course, would have never happened. Although the Nova Scotia tartan was worn on some official occasions soon after its invention, Scottish clans still prefer to wear their own traditional tartans. This has not stopped a mass production of all kinds of Nova Scotia tartan souvenirs available for tourists all around New Scotland.

An amusing Highland caricature appears in the cover of R. A. MacLean's A State of Mind: The Scots in Nova Scotia:xxxviii 
the Scottish bagpiper holds a huge tartan instrument in the shape of the Nova Scotian peninsula. To reinforce the message conveyed in illustration, the back-cover blurb points out how the author 'captures the essential Scottishness of Nova Scotia' ${ }^{x x x i x}$ The author, however, suggests a critique to the Scottish Highlands myth developed in Nova Scotia:

Today the first image often conveyed when one hears the term Scot is that of someone in a kilt; this is hardly fair to a Lowland resident [...]. That modern image of the Scot is largely the invention of modern script writers and advertising personnel willing to trade off a bit of romance for commercial gain. ${ }^{\mathrm{x}}$

The stereotypical bagpiper reappears on the cover of F. Emerson's Scots, xli an account of the Scottish influence in all aspects of modern cultures and traditions of the Maritime Provinces of Canada. The book, a brief account of the Scottish immigration to Atlantic Canada and its long-standing traditions, is part of The People of the Maritimes series, which aims to analyze the distinct ethnic groups 'and the role they have played in shaping the character of the Maritimes' xlii

Despite the cliché imagery of the cover illustration, this monograph suggests a new attitude towards the Scottish heritage, not as the Culture but as a part of the cultural mosaic that Canadian policy has started to encourage. It is not surprising that The Maritimes People Project has been funded by the Minister responsible for Multiculturalism.

The last section of this analysis moves onto tourism and the role played by tourism in the development of a Scottish iconography in Halifax. Multiculturalism has to be the key word to understand the policy lately undertaken by the tourist board in Nova Scotia. In the last decade of the twentieth century, the tourist board for Nova Scotia has attempted to develop new strategies in order to promote the establishment of a cultural tourism throughout the province. Taking inspiration from a general tendency all over the world, and the multiculturalism now strongly present in the image that 
the Canadian Government and Canadian Heritage are trying to offer, the tourist board has studied the opportunities to open new markets by using the multicultural heritage of Nova Scotia.

The components of Nova Scotia cultural heritage have been converted into actual products manufactured, advertised and finally sold to visitors. ${ }^{x}$ liii Among the four main ethnic groups of Nova Scotia (Acadian, Mi'kmaq, African Canadian and Gaelic) the latter appears to have certainly been 'exploited' thoroughly since the advent of premier Angus L. Macdonald, whose role in the promotion of Scottish events and heritage has been seen in the introduction. Macdonald's lesson seems to have reached far and its effects are still visible in the modern tourist industry. In other words, although the other ethnic communities are definitely making their mark in the tourist industry of the province, Scottish (tartan) imagery is still effectively, though at times ambiguously, used to encourage sales of tourist products.

Real bagpipers are a constant feature in Nova Scotia, especially in tourist spots. Peggy's Cove, a fishing village half an hour from Halifax, has been turned into a real tourist hive, although it has recently experienced a crisis due to the Swissair plane crash of September 1998. The airline company compensated fishermen for their losses, but two bagpipers are now suing the company because they claim their tourist seasons have been spoilt by the accident. The most ironic detail of this rather amusing lawsuit is, perhaps, that the pipers are - contradicting the Scottish tradition - two kilted women. xliv

Private tour operators have found the Scottish theme particularly effective in their advertising campaigns. Among others, Atlantic Tours, a leading company in the Canadian tourist industry, call themselves 'The Company with the Kilts'. The tour guides lead tourists around Nova Scotia in the traditional Scottish attire. The tartan they wear can be Scottish or Nova Scotian. The company offers several optional tours to Scottish and non-destinations. The kilted guides will take visitors to Lunenburg, a village with a strong German- 
Hanoverian tradition and along the Evangeline Trail, to visit the French Acadian area of the Province, as well as to the usual Scottish Mecca, Cape Breton Island. The emphasis given to the wearing of the kilts has lost its cultural significance and has, instead, assumed a commercial value based on the proverbial stereotype of the Scottish tightness. In the Atlantic Tours (kilted) president's words: 'I invite you to compare... Dollar for dollar, we offer the very best there is in value-for-money vacations...'. xlv $^{\prime}$

Scottish imagery, stereotypes and jokes have become a source of inspiration for advertising purposes and generally encourage consumers to buy. Products are often meant for the tourist market, but there are some exceptions that will be taken into consideration later. Advertising and marketing strategies have also had their share in the proliferation of Scottish imagery in Nova Scotia. The wide range of 'Scottish' souvenirs on sale at the several gift shops in Halifax is rather impressive. Tartan, once again, is the triumphant pattern for all sorts of products in variable degree of tastelessness. Canvas posters reproducing the most famous tartans are shelved together with tartan scarves, ties, kitchen aprons, napkins and gift-wrap. Cheap jewelry is manufactured reproducing bagpipes and pipers, thistles and Celtic patterns. 'Scottish slogans' such as 'Bagpipes Spoken Here', 'Up Yer Kilt!' and 'If It's not Scottish it's Crap!' are reproduced on Post-IT sticky note-pads. Most of these products are meant for tourists, but some, like Scottish Clans Post-It note pads, seem to be directed also to local markets. ${ }^{x l v i}$

Tartan imagery and stereotypes reappear in the next two examples of this overview. ICELANDAIR has used two kilted puffins to advertise its trans-oceanic flights in an advertisement found in the April 1999 issue of Celtic Heritage. This is how the Scottish puffins comment on the special offers:

'Hae ye flown wi' ICELANDAIR to Scotland yet, laddie?'

'Aye, their wee fares help me keep my pennies in my sporran!'xlvii 
Playing on the traditional cliché about Scottish frugality, the two puffins are actually promoting the possibility of visiting Iceland on a special package offered by ICELANDAIR for travelers flying to Glasgow via Reykjavik. The ubiquitous cliché returns, along the same lines, as the inspiration behind the loyalty scheme at Canadian Tire stores. With each purchase at any of the stores, customers are given discount vouchers valid on their next visits. The campaign available also on line allows shoppers to accumulate riches on a credit card if you are a member of My Canadian Tire. 'Canadian Tire Money' vouchers portray, instead of the Queen, a smiling Scotsman in a tartan scarf, reinforcing the amusing stereotype about Scots and money.

A different angle was chosen a few years ago when Scottish heritage and ancestry become part of the advertising campaign for the now defunct New Scotland Brewing Company. In 1999, on their website as well as on their bottles it was possible to read a concise version of the history of the province - and their beer. Linguistic inaccuracy aside (English and Highlander used in place of British and Scottish), both the province and the beer allegedly originated from the Hector. It was (supposedly) from the smoked oak shavings of the reconstructed mythical ship that some of the New Scotland Ales reached their unique blend. The final thought was, once again, for the Scottish heroes: 'When you hoist a Scotsman Ale, whether or not you are of Scottish decent, give thanks to those hardy pioneers who carved from the wilderness the communities we call home'. No mention, of course, of the previous native settlements that really opened up the wilderness to the European 'pioneers'.

This article started with a critical introduction to the history of the Scottish immigration to Nova Scotia and the myth of the Scottish Highlands the immigrants imported from the fatherland. Focusing on Halifax, vestiges of Scottish heritage have been shown to persist in a great variety of formats, from buildings, to the local flora and current printed sources. The visual Scottish icons analyzed in the first two sections, represent the link to the third angle of this analysis: 
the persistence of Scottish imagery in the development of cultural tourism in Nova Scotia, as well in the general advertising business. What does tartan imagery mean today in Nova Scotia? Is Scottish heritage only a big tourist trap? There is certainly a great deal of what MacKay calls 'Tartanism' surrounding the tourist industry in Nova Scotia, as shown in all the uses of tartan and Scottish imagery considered above. Several of the Scottish icons discussed seem to have either lost their meaning or simply become part of a superficial decorative motif without significance. The use of Scottish icons for commercial purposes, has, clearly, contributed to this process in a drastic way. If Scottish tartan is featured on any kind of cheap product, how can it still represent proud Scotsmen's national identity? How can Scottish people not feel deprived of their own cultural heritage by the demands of the tourist industry?

On the other hand, institutions like the North-British Society existed long since before the tourist boom started. They were conceived as charitable institutions to support immigrants in Nova Scotia. They promoted the continuity of Scottish traditions abroad in order to give a genuine cultural identity to the communities. The Halifax and Antigonish Highland Games have now been celebrated for more than a century, which is a long time in terms of North American traditions. The Highland myth has played an important role in the making of Scottish national identity, despite all the stereotypes attached to it and the commercial uses that have been made by the tourist industry. A very similar situation, it can be argued, exists in Nova Scotia. The perpetration (and invention) of traditions and the use of tartan and kilts are genuinely felt among Scottish immigrants as important as it is by the Scots in Edinburgh. It is, beyond all the criticism to its antimodernism, a powerful symbol of identity and kinship for all the Scots who, Lowlanders and Highlanders, have attempted for centuries to assert their independence against the dominant English culture:

We may find tartanry, Bonnie Prince Charlie, Mary Queen of Scots, Bannockburn and Burns 
false descriptors of who we are, but they provide a source of ready-made distinguishing characteristics from England, our bigger, southern neighbour. ${ }^{\text {xlviii }}$

A broader angle helps understanding the reasons behind the tartan icons and reinforces their validity as symbols of a genuinely felt national identity. A parallel, as Cowan has suggested, xlix can be drawn between England and Scotland and United States and Canada. In this light, tartan is a cousin to the maple leaf - the profusely used and abused symbol of Canadian identity. Canadian Heritage promotes the use of the national symbols to assert national identity. Canadian flags can be seen at petrol stations, supermarkets as well as in clothing and tourist souvenirs throughout the country, in what could be identified as an explosion of 'Mapleism'. Canadians traveling abroad often carry small maple leaf icons to assert their identity and avoid being mistaken for Americans. Scottish Canadians wear tartan, doubly concerned about their identity: they are Scots (not English) and Canadians (not Americans).

University of Glasgow

\section{End Notes}

i See C. Withers, 'The Historical Creation of the Scottish Highlands', in The Manufacture of Scottish History, ed. by C. Whatley (Edinburgh: Polygon, 1992), pp.143-156.

ii See John R. Gold and Margaret M. Gold, Imagining Scotland (Brookfield: Vermont, 1995), pp.62-83.

iii E.J. Cowan, 'The Myth of Scotch Canada', in Myth, Migration and the Making of Memory: Scotia and Nova Scotia c. 1700-1990 ed. by Michael Vance and Marjory Harper (Halifax: Fernwood Publishing Ltd., 2000), p.63.

iv Cowan, p. 59. 
International Review of Scottigh Studies $\mathfrak{Y}$ Ool. 282007

v See Rusty Bitterman, 'On remembering and Forgetting: Highlands within the Maritime Diaspora', in Vance and Harper, pp.253-266. See also Ian MacKay, 'Tartanism Triumphant: The construction of Scottishness in Nova Scotia', Acadiensis, XXI, 2 (1992) 5-47.

vi See Vance and Harper.

vii Cowan, p.60.

viii Robyn Blois, Pictou Advocate, 21 April 1999.

ix See D. Campbell and R. A. MacLean, Beyond the Atlantic Roar: A Study of the Nova Scotia Scots (Toronto: McClelland and Stewart Limited, 1974), p.32. See also MacKay 1992, p.8.

x See Profile of Census Divisions and Subdivisions in Nova Scotia, Ministry of Industry, Ottawa, 1999.

xi See Profile of Census Tracts in Halifax, Ministry of Industry, Ottawa, 1999.

xii See MacKay 1992 and Cowan.

xiii See Ian MacKay, The Quest of The Folks (Montreal: McGill University Press, 1994).

xiv MacKay 1992, p. 6.

xv 'About the Heather', Morning Chronicle, 13 August 1878, col. 3.

xvi'Correspondence', Morning Chronicle, 13 August 1878, col. 3.

xvii E. E. Prince, 'Rose Shamrock, and Heather', Dalhousie Review, vol. 8, April 1928, p.54.

xviii See Prince.

xix Campbell and MacLean.

xx ، "Monstrosities" for the Park', Halifax Mailstar, 27April 1967, p.3.

xxi See Gold and Gold, pp.184-191.

xxii 'From J. A. Chilsom to Major General Maxwell Scott', February 25 $5^{\text {th }} 1932$, Scott's Monument Documents, Public Archives of Nova Scotia, Halifax. 
xxiii 'Handsome Bust of Scott Presented', newspaper article, Scott's Monument Documents, Public Archives of Nova Scotia, Halifax.

xxiv 'Cairn to Commemorate Province's Founder', Halifax Mailstar, 9 May 1957, p.4.

xxv Elizabeth A. Chard, ed., Academic Calendar Saint Mary's University, (Halifax, 1998), p.7.

xxvi Chard, p.7.

xxvii See P. B. Waite, The Lives of Dalhousie University, vol. 1, (Montreal: McGill and Queen's University Press, 1994).

xxviii G. M. Acklom, 'The College Coat of Arm', Dalhousie Gazette, 7 March 1903, pp.216-224.

xxix See Halifax Citadel National Historic Park, Management Plan (1979 9, p.176.

xxx 'The 78 ${ }^{\text {th }}$ (Highland) Regiment of Foot or the Ross-Shire Buffs', Parks Canada Information Sheets, Halifax Citadel Archives.

xxxi 'The Kilties', Morning Chronicle, 17 May 1869, p.3.

xxxii See Halifax Evening Reporter, 15 May 1869, p.1; Halifax British Colonist, 18 May 1869, p.2; Halifax Citizen, 18 May 1869, p.2; The Presbyterian Witness, 22 May 1869, p.164; The Christian Messenger, 19 May 1869, p.155; C. Pulsifer, The 78 th Highlanders in Halifax, 1869-1871: the Experiences of a Highland Regiment in a Garrison Town, vol. 1, Halifax Citadel Archives, 1983.

xxxiii See 'Historical Background', Halifax Defense Complex Guide Handbook, Halifax Citadel Archives, 1993.

xxxiv 'The 78 th (Highland) Regiment of Foot, or The Ross-Shire Buffs', Parks Canada Information Sheet, Halifax Citadel Archives.

xxxv Jean MacKaracher Watson, 'Scots Not Considered a Culture', Celtic Heritage, vol. 12, 2, April/May 1999, p.6.

xxxvi The Scottish Banner, April 1999, p.1.

xxxvii Marjorie Major, How Nova Scotia Got Its Tartan (Halifax:

The Book Room, 1996). 
International Review of Scottigh Studies $\mathfrak{Y}$ Ool. 282007

xxxviii R. A. MacLean, A State of Mind: The Scots in Nova Scotia (Hantsport: Lancelot Press Limited, 1992).

xxxix MacLean, back cover.

${ }^{x l}$ MacLean, p.35.

xli F. Emerson, Scots (Toronto: Nimbus Publishing Limited, 1997).

xlii Emerson, back cover.

xliii See Nova Scotia Cultural Tourism Study, (Halifax: Nova Scotia Economic Development and Tourism, 1997).

xliv Sherry Borden, 'Bagpipers file suit against Swissair', The MailStar, 26 May 1999, 1.

xlv Paul Emmons, Atlantic Canada, Atlantic Tours Gray Line, Tourist Brochure, 2000, 3. See also their website, www.atlantictours.com.

xlvi The Scottish Banner, April 1999, p.18.

xlvii See the back cover of Celtic Heritage, vol. 12, 2, April/May 1999.

xlviii David McCrone, Scotland: The Brand. The Making of Scottish

Heritage (Edinburgh: Edinburgh University Press, 1995), p. 7.

xlix Cowan. 